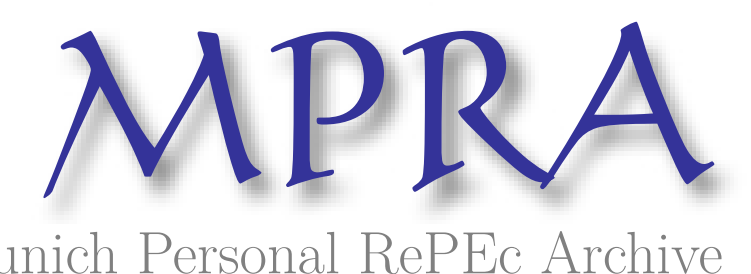

Munich Personal RePEc Archive

\title{
CHALLENGES IN INTRODUCING DISTANCE EDUCATION PROGRAMME IN ERITREA:Some Observations and Implications
}

Rena, Ravinder

Department of Business and Economics, Eritrea Institute of Technology, Mai Nefhi, Asmara, The State of Eritrea

October 2006

Online at https://mpra.ub.uni-muenchen.de/10582/ MPRA Paper No. 10582, posted 27 Sep 2008 23:50 UTC 


\title{
CHALLENGES I N I NTRODUCI NG DI STANCE EDUCATI ON PROGRAMME I N ERI TREA: Some Observations and I mplications
}

\author{
Dr. Ravinder RENA \\ M.A., B.Ed., LL.B., M.Phil., Ph.D. \\ Assistant Professor of Economics \\ Dept. of Business and Economics \\ Post Box No: 7956 \\ Eritrea Institute of Technology - Mai Nefhi \\ (Under the Ministry of Education) \\ Asmara, ERI TREA
}

\section{ABSTRACT}

All over the world, distance mode of education is gaining a momentum and becoming more popular than conventional education. It is a system in which schools, universities and other educational agencies offer instruction wholly or partly by mail. Eritrea is a newly independent country in Africa is been facing many challenges particularly in its education sector. It did not have more educational institutions at tertiary level. Thus the distance learning is the best option for this country. An attempt is made in this paper to discuss various problems related to the establishment and development of distance education. It also provides the distance education programmes so far undertaken in the country with concluding remarks.

Keywords: Distance Education, Eritrea, Ministry of Education, Asmara University.

\section{NTRODUCTI ON}

All over the world, it is now evident that distance mode of education is gaining a momentum and becoming more popular than conventional. It is to be noted that the learners in developed countries preferring distance learning to conventional education. The Distance Education (DE) is an educational phenomenon that marked a big educational and structural change in a short duration of time than the preceding schools of education (Harry, 1992). It has become a vital issue in education and in strategic planning for regional, national and international development (Khan, 1993; Keegan, 1996; Wills, 1998). Since the tertiary education is costlier than school education, many countries have developed policy frame works for the development of distance education at tertiary level for the fact that it promotes further education to upgrade and update the skills and the knowledge of the contact students. In addition, it creates the possibility of increased access to tertiary education at more cost effective-level (Terry and Juler, 1991; Saint, 1999). Mass education is attained through distance learning because of modern technology where the world is becoming boundary less. Technical developments have greatly contributed for the development of distance education (Daniel, and Mega, 1996; Rumble, and Oliveria, 1999). Further, distance education is changing with an alarming speed, particularly as educational processes become increasingly globalize in terms of physical reach and scope of 
Rena, Ravinder (2007) "Challenges In Introducing Distance Education Programme In Eritrea - Some Observations and Implications" Turkey: Turkish Online Journal of Distance Education-TOJDE (ISSN 1302- 6488), (January), Vol.8. No.1. Article 15. pp. 191-205. tojde.anadolu.edu.tr/tojde25/pdf/article_15.pdf

courses and programmes of study offered. Eritrea has launched distance education programmes but hampered due to various factors. The world map vividly shows that Eritrea is strategically located in the horn of Africa, sharing border with the Sudan to the north and west, Ethiopia to the south, Djibouti to the south east and the Red Sea to the east respectively. It has a human population of about 4 million. It covers an area of $124,320 \mathrm{sq} \mathrm{kms}$, stretching from 18.22' to 12.42' degrees longitude. Eritrea's coastlines extend about $1200 \mathrm{kms}$, flanked by coral reefs and 354 islands, including the important Dahlak Archipelago (Killion, 1998:1; Rena, 2005 a ). The war devastated nation fought for thirty years (1961-1991) bravely to obtain its de facto independence on 24 may 1991 and its official independence on 24 May1993 after a UN supervised referendum in which $98.8 \%$ of the people voted in favour of independence (MoE, 1999; Rena, $2005^{\mathrm{b}}$ ). Soon after the independence it has been working ceaselessly to develop the education in the country. Distance Education is at its infancy.

\section{Why Distance Education in Eritrea?}

The curriculum designers and makers while trying to publish quality school books to all grades had the main pre occupation how to increase the number and improve the quality of the learning force against the daunting background of: $i)$ The acute shortage of teachers after liberation in 1991 to staff the schools; ii) The limited capacity of the one teacher training (ATTI) and its subsidiary branch Eritrea Institute Technology (EIT); iii) An enormous increase in elementary school enrolment and thereby construction of many new schools; iv) A two years university diploma has for long been a technical requirement for being middle school teachers in the country; v) The reluctance because of cultural or religious reasons of females or members of some ethnic groups to move away from their homes and families for training purposes; vi) The economic and domestic difficulties that prevent many teachers, particularly from remote regions from taking up training away from their localities; and vii) The need to educate the disadvantaged irrespective of age, sex and place.

Whilst spending on educational provision has increased greatly, there are limited budgetary means to cater the financial costs that a new nation has to face when rebuilding infrastructure expanding medical, and welfare services and advancing economic and business opportunities (Rena, $2005^{\circ}$ ).

The data is collected from different sources related to distance education both from the public sector and the private sector. Informal discussions made with many concerned people and the stakeholders of this distance programme. The government officials (related to this program), students and staff of the College of Education in Eritrea Institute of Technology (EIT)-Mai Nefhi; Asmara Teacher Training Institute, elementary teachers (who are learning their distance education in Asmara University).Teachers working in some secondary schools (of Zoba Maekel) like Red Sea, Asmara Comprehensive, Barka, Denden, I ssak Teweldemedhn and some students and employees are contacted and discussions held with them. All in all 10 directors (including heads), 30 teachers, and 60 students at all levels are contacted. An in-depth interview is conducted with them. The data also collected from the relevant documents. Besides, researcher also used open ended interview in order to free the interviewee to discuss openly when asked. The study was conducted during the period October 2005 to March 2006.The paper is been organized into five sections. The second section provides the distance education programmes implemented in Eritrea. Section three discusses the challenges for the DE in its implementation in the country. Section four provides some policy implications in the implementation of the DE programme. The final section provides the concluding remarks. 
Rena, Ravinder (2007) "Challenges In Introducing Distance Education Programme In Eritrea - Some Observations and Implications" Turkey: Turkish Online Journal of Distance Education-TOJDE (ISSN 1302- 6488), (January), Vol.8. No.1. Article 15. pp. 191-205. tojde.anadolu.edu.tr/tojde25/pdf/article_15.pdf

\section{STANCE EDUCATI ON I N ERI TREA}

The Ministry of education declared the policy that extended education opportunities to all Eritreans irrespective of their age, sex and geographical location in Eritrea. ${ }^{1}$ Besides, Eritrea proposed that it be included as one of the "Fast track" EFA (Education for all) countries, to hasten its educational progress.

In line with this, it has made a lot of changes to assure the correct implementation of a standard system of education wholly put in practice in schools of different levels. The teachers in return were/ are given successive professional training in work shops, seminars, and short and long term refresher courses to up grade their professionalism and work esteem (Rena, 2006). Many schools were/ are built equipped with modern mode of teaching learning mechanisms. Meanwhile the government is following required implementation of:

$>$ Significant expansion of integrated, low cost and community based early childhood programmes;

$>$ Universal access and quality primary education for all to be by 2015 Parallel to reducing male illiteracy to about 10 percent by 2010, achieve female literacy of at least 60 percent; and

$>$ Expanding 'life long' learning to achieve a modern cultural transformation among disadvantaged groups in rural and urban areas through distance education mode of delivery(MoE, 2006).

Asmara University is given the authority to give immediate answer to the implementation to give "equal opportunity" at tertiary level education offering distance education. Indeed, no system of distance education can remain efficient if it remains static. It must be sensitive to trends and changing need in education, and must have the flexibility to modify its programme and practices, and to expand in response to the needs of the community it is serving. Ministry of Education has recognised the above issues and is working on the importance in improving the education system in Eritrea (Rena, $2005^{\mathrm{b}}$ ). I ts vision is ultimately to attain particularly a quality of education, access and relevance. Distance learning, a new mode of delivery, would undoubtedly promote educational quality and relevance in many ways, if we all work on the validating role of distance education (MoE, 1999; Rena, 2006). The Ministry of Education is embarking the strategies to resolve the problems mentioned above by supplementing proper distance education programmes in the schools that it aims to establish soon. Thus, the Institutions to be established require better managerial skills than conventional programmes. In the past one and halfdecade, one of the government's main priorities was to rebuild, expand and improve the educational system by developing policies that would favour greater access, equity and quality of education(Rena, 2005 ${ }^{\mathrm{a}}$; MoE, 2003).

The Distance Education Programs for Elementary Teachers (DEPETE) in Eritrea Under the DEPETE program, the Ministry is striving to up-grade knowledge and skills of teachers qualitatively and quantitatively. The DEPETE programs are discussed hereunder: With a view to impart quality education and create a professional work force to cater to the nation's need, the state of Eritrea now has adopted a rapid transformation policy to bring about an effective change in the education sector in 2003. This lays out long term vision and strategy to lift Eritrea forward. Along side the 
Rena, Ravinder (2007) "Challenges In Introducing Distance Education Programme In Eritrea - Some Observations and Implications" Turkey: Turkish Online Journal of Distance Education-TOJDE (ISSN 1302- 6488), (January), Vol.8. No.1. Article 15. pp. 191-205. tojde.anadolu.edu.tr/tojde25/pdf/article_15.pdf

increase in the number of schools and students, there has been a marked increase in the number of teachers (Araya, 1998). In 1991, there were 4,504 teachers about half of these were Ethiopians who immediately left for Ethiopia of their ow $n$ will there by creating an acute shortage of teachers. While there are many different factors that play a role in improving the quality of education, teachers academic and professional qualification is very crucial. Hence distance education will improve the quality of teacher education in particular and the quality of education in general (Taye, 1992; Rena, $2005^{b}$ ). The need to have effective and efficient teachers could promote the standard of education sooner or later as aimed by educators in the department of curriculum. The programme of teaching teacher was initiated with funding from the I talian government and technical assistance from UNESCO. Five hundred untrained teachers from three regions (zobas) - Debub, Gash Barka and Northern Red sea were involved in summer 1996 (Ministry of Education, UNESCO and the Government of I taly, 1996). It was phase-I, the pilot phase, which evolve trainees required to attend:

$>$ Two-five week face-to-face workshop sessions at the main regional training centres during the 1996 and 1997 summer vacations;

$>$ One mid year workshop for two weeks in February 1997 at the main regional training centres; and

$>$ Monthly tutorial/ workshops at the local teacher resource centres with trainees receiving self-instructional correspondence texts through the academic year.

There was a continuous assessment throughout the programme with assignments, tests, projects, work set as part of the work shop sessions. Assessments were also made on the classroom practiced of the trainees. Examination was given and the examinees who succeeded received a certificate equivalent to that awarded to graduate of the Asmara Teacher Training Institute (ATTI). The DEPETE (Distance, Education programmes for Elementary Teachers in Eritrea) programme was regarded as a vital element of the Ministry of Education which was embarked to improve the quality and quantity of qualified teachers at elementary level, while the pilot was in progress preparations were also going on to include 1,500 unqualified elementary teachers from all six zobas with special priority to the other remaining three zobas already excluded in the Phase-1 (Maekel, Anseba and Southern Red Sea). There some funding problem initially, however the Ministry was anxious and determined to continue the program and tried its best to look for a reliable and sustainable source of funding not only to undertake phase-II but also to advance in the future years till all untrained/ unqualified/teachers in the system are trained through distance learning along side the conventional (traditional) learning (Araya, 1998).

The main objectives of DEPETE were $t$ :

1. Provide in-service - training programmes for approximately 2,000 untrained elementary school level teachers through a distance learning model of teaching.

2. Establish a capacity and lay a foundation for developing a distance learning organization for teachers and other educational staff in the national school system.

3. Through provision of a local based training programmes, encourage and enable more female trainees and also those from the ethnic groups to participate (marginalized groups)

4. Indirectly give feed back to the present initial teacher training programmes

5. Institute and promote the role that Teacher resource centres can in local and in service training. 
Rena, Ravinder (2007) "Challenges In Introducing Distance Education Programme In Eritrea - Some Observations and Implications" Turkey: Turkish Online Journal of Distance Education-TOJDE (ISSN 1302- 6488), (January), Vol.8. No.1. Article 15. pp. 191-205. tojde.anadolu.edu.tr/tojde25/pdf/article_15.pdf

6. Promote an effective system DE training programmes in Eritrea.

7. Continually upgrade and train teachers, school directors supervisors and other educational staff through a Distance Education model without separating them from their work.

8. Continue to the promotion of quality education in an equitable way.

\section{Rationales for DEPETE}

The distance education programmes for elementary teachers in Eritrea (DEPETE) is an attempt to overcome some of the above problems from the limited experience of distance education known as DEPETE has the following rationale to bear in mind. Hence, it was emphasised that the Ministry of Education provisions in order to:

1. I ncrease access of learning and training opportunity

2. Reach target groups with limited access to conventional education

3. Support the quality of existing educational structures.

4. I mprove cost effectiveness

5. Enhance and consolidate capacities

6. I ncrease greater flexibility in the design and delivery of curriculum content than is normally associated with class room teaching.

The quality of teaching defines the quality of education and the quality of education in turn facilities the contribution that the next generation of teachers is able to offer to learners. While there are a number and different variables and factors in class room effectiveness, the most important component is the teacher. Moreover, the government's decision to extend the middle school cycle (programme) from two to three years in 2003/ 04 academic year has created a further pressure to the desperate demand for teachers in middle schools. The critical shortage of qualified teachers mainly at the primary level has been the key challenge for educational development. Therefore, redressing the huge demand for teachers and improving the quality of teaching and learning process still remains to be formidable task. The researcher felt resourceful in his studies after he deeply assessed all the researches made by the Ministry in its firm establishment of distance education programs right after independence, even if, some of the distance education program implementations failed due to certain constraints mentioned by the researcher.

\section{CHALLENGES FOR DI STANCE EDUCATI ON PROGRAMME}

Why the Ex-distance Learning in Eritrea Ceased?

The DEPETE programme launched to improve elementary teachers work esteem and professionalism. This improvement throughout distance learning was successful for which the staff authorities in the Ministry of Education, I talian government and UNESCO should be proud of. It will render more help for its continuity to updating and upgrading teachers who could possibly alleviate the standard education system along with the country's development. The discontinuity of the distance education sector before seven years is not amazing. It was because of lack of expertise, lack of experience, logistic, quality materials and student support services. Spending on educational provision has increased greatly. The government of Eritrea being new government that inherited destroyed infrastructure and low human power due to the wars that passed and the border dispute could not fulfill the demands of its people as it wishes. 
Rena, Ravinder (2007) "Challenges In Introducing Distance Education Programme In Eritrea - Some Observations and Implications" Turkey: Turkish Online Journal of Distance Education-TOJDE (ISSN 1302- 6488), (January), Vol.8. No.1. Article 15. pp. 191-205. tojde.anadolu.edu.tr/tojde25/pdf/article_15.pdf

\section{Hindrances Suggested by Asmara University Committee}

The study project is not a through feasibility study of establishing whether a distance education is the right thing to do at this time. But it rather a study limited on designing and proposing structural framework, required facility and a time to start it (Araya, 1998). This limitation led the committee division in Asmara University to mark some basic assumptions that:

$>$ There is enough demand for distance education

$>$ There will be reasonable postal and communication services infrastructure in the country.

$>$ There will be enough resources to establish it.

The other limitation of the study is that the distance education programme be an integrated part of the current regular and extension programmes leading to a uniform undergraduate degree.

$>$ The admission requirements to the distance education programme are that same to that of the regular and extension programmes.

$>$ The content of the course and the standard of examination of distance education is the same to that of the other two programmes.

$>$ The academic staffs of the Asmara University are going to be flexibility in all of the three programmes.

Faculty Barriers in Distance Learning Programs in Eritrea

1. The biggest problem for distance programs is the lack of support by the faculty. The endorsement by department faculty is viewed as a critical instruction element in any distance education program. Faculty roles must change the most in administering distance learning programs (Rena, $2005^{\mathrm{c}}$ ). They may change teaching styles to that of a mentor, tutor and facilitator. They must meet the needs of distance students with face-to-face contact. Since the majority of distance learners are adults, teachers may need to change their teaching style. This may be a challenging for teachers who are used to teaching 18 to 22 years old. Faculty is responsible for changing their course content to accommodate diverse student needs and expectations. So long as college faculty feels there is a burden associated the distance education programme currently in place, there will be little support for expanding distance education opportunities.

2. Teachers may lack the basic skills or hardware to fully participate in distance education. It is interesting to note, however, that students respond to this changing environment more adeptly than teachers do. Obtaining proper equipment and training is critical in teacher acceptance of distance learning.

3. Another problem perceived by faculty is the threat to tenure and human resource staffing. Depending on the school and the academic department, courses taught as part of a distance program may not always count toward tenure considerations thus causing a disincentive for participation by some non-tenured faculty (Wood, 1996) if one professor can serve thousand of students there will be obviously be fewer professors and fewer departments and faculties. Schools must not underestimate this resistance and should be very aware of the possibility of overburdening faculty and staff.

4. Teachers also have problems respecting the academics of distance courses. One way of enhancing commitments is by forcing distance courses through the same approval process an on-campus course. The final barrier is the teacher's acceptance of distance learning programmes. Teachers with enthusiasm for thin non-traditional 
Rena, Ravinder (2007) "Challenges In Introducing Distance Education Programme In Eritrea - Some Observations and Implications" Turkey: Turkish Online Journal of Distance Education-TOJDE (ISSN 1302- 6488), (January), Vol.8. No.1. Article 15. pp. 191-205. tojde.anadolu.edu.tr/tojde25/pdf/article_15.pdf

course work are best suited to teach them. One way to mitigate these potentially serious problems is by selecting teachers who are relatively senior people, good teachers, like the idea of distance learning and want to participate in it. Interest and motivation are not success factors reserved only for the student. Faculties who want to teach distance courses are certainly more likely to be successful than faculty that are forced to teach these courses.

\section{Organisational barriers in Eritrea}

Students and teacher concerns represent the human aspects of distance programmes. Organisational problems, especially infrastructure and technology problems, also present challenge. Faculties who teach distance education courses need organisational and administrative support from the Institution. Funding should be provided to create an administrative unit that is to be responsible for managing the programme. Institutional teachers must be committed to distance programmes. (Marrs 1995:21) agrees when he says, "without this support, distance education is at risk of significance to the Institution". A primary concern for both learning Institutions and students is available for both the student and the Institution. Institutions must consider the initial costs as well as the continuing costs of installing, maintaining, using and upgrading technology to support distance services. Institutions must also plan to have competent computer staff to support internet use. This staff must then be kept up-to-date on the newest, fastest, cheapest technology available; therefore, on going staff must be considered. The student must also incur technology costs, if the internet is used, then the student must have access to a computer, modern and associated software.

In addition to cost considerations, the technology itself presents many problems; one issue is in adequate telecommunications facilities. Harry (1992:190) mentions that "the existing telecommunications systems are unlikely to place too much reliance on them for teaching, support or information searching." That is the reason why some developing countries will use, print, cassettes, and radio delivery methods. Such circumstances prevent some instructors from producing or using advanced media and providing higher quality material for students. Distance education via simultaneous two-way-audio-visual interaction systems such as video teleconferencing, brings an additional set of issues to be considered by the instructor and effective models for this delivery system need to be identified (Sweet, 1986). Asmara university, given its unique socio potential environment and resource constraints is likely to be one of the "mixed - mode department model" of Institutions, to find a solution to the crucial points above believing that the development of national distance education capabilities being the stepping stone by which all nations will proceed into the future.

\section{RESULTS AND DISCUSSION}

1. Time constraints were another limiting factor that hinders the depth and width of the study.

2. The committee was not able to get in time relevant, up to date and enough literature to conduct the study.

3. With scattered students, dispersed part-time tutors, far-flung logistics, reliable communication services, time sensitive communication services, time sensitive production and distribution of learning materials, and detailed student records, 
Rena, Ravinder (2007) "Challenges In Introducing Distance Education Programme In Eritrea - Some Observations and Implications" Turkey: Turkish Online Journal of Distance Education-TOJDE (ISSN 1302- 6488), (January), Vol.8. No.1. Article 15. pp. 191-205. tojde.anadolu.edu.tr/tojde25/pdf/article_15.pdf

successful distance education programmes require management team with above average skills in organisation, logistics and problem solving. This management team need not be large, but it must be capable.

4. Students who enroll in distance learning courses do so for convenience. They are either time bound due to work or travel schedules or location-bound due to geographic or family responsibilities. ${ }^{2}$ Distance learning is student-centred learning; thus knowing the characteristics and demographics of the distance learners helps us understand the potential barriers to learning.

5. Problems and barriers encountered by the student fall into several distinct categories; student support and services, alienation and isolation, lack of experience, and training. Distance learners are more likely to have insecurities about learning and these insecurities are founded in personal and school related issues such as financial costs of study, disruption of family life, perceived irrelevance of their studies and lack of support from employers. These pressures often result in higher dropout rates than among traditional students (Sweet, 1986).

6. The concern for the distance student is the perceived lack of feedback or contact with the teacher. Because there is not daily or weekly face-to-face contact with teachers, students may have trouble in self-evaluation. Keegan (1996) believes that the separation of student and teacher imposed by distance removes a vital "link" of communication between these two parties. The link must be restored through overt Institutional efforts so that the teaching-learning transaction may be "reintegrated "(Keegan, 1996:120). These barriers can be mitigated through technological method such as e-mail, computer conferencing and electronic mail can be integrated into the delivery of the course to provide the missing interaction. It is important that the student receive prompt feedback in any Institutional setting particularly in distance learning where the learner is impaired by the lack of causal contact with the teacher and other students. This is especially important for those students who live outside metropolitan areas. They may not have access to reliable telecommunication, computers and postal mail. The frustrations resulting from problems with communication between student academic Institution are factors of which distance education planners should be aware (Wood, 1996).

7. Area of concern distance students is the lack of support and services such as providing tutors, academic planners, schedulers, and technical assistance. The isolation that results from the distance learning process can complicate the learning process for adult students, support for distance learners should not be overlooked when planning distance programmes, students need tutors and academic planners to help them complete courses on time and to act as a support system when stress becomes a problem.

8. A problem area is the feeling of alienation and isolation reported by distance students. Students of all kinds want to be part of a larger school community, and simply of "a correspondence" course. The "distance" aspect of distance learning takes away much of the social interactions that would be present in a traditional learning environments.

9. A problem is prevalent with newer distance students. If distance learning Institutions is serious about providing equity of educational opportunity to all, then 
Rena, Ravinder (2007) "Challenges In Introducing Distance Education Programme In Eritrea - Some Observations and Implications" Turkey: Turkish Online Journal of Distance Education-TOJDE (ISSN 1302- 6488), (January), Vol.8. No.1. Article 15. pp. 191-205. tojde.anadolu.edu.tr/tojde25/pdf/article_15.pdf

careful consideration must be given to the special needs of students undertaking distance education for the first time. Of particular importance is the design of study materials for distance students.

\section{The Determinants for Effective Distance Learning}

It is believed that open/ distance learning could play a very useful part in any given country's education sector development plan. It could be helpful provision in meeting some the many professional development and upgrading needs the country's plan identifies and priorities. All effective distance learning programmes depend upon "three legs" of good learning materials, effective student supports, and efficient logistics (Moore, and Kearsley, 1996).

\section{Good learning materials}

The type of the teaching materials to be prepared depends on the objectives and financial resources of the Institution. That is depending on the short and long range plan and objectives of the Institution, teaching materials will have to be prepared in terms of priorities. Moreover, the variety of the teaching materials depends on the Institutions available financial resource. The more the resources the more the varied the teaching materials become. For example, if the Institution has sound financial resources, It can in addition to printed material, use radio and television provided there facilities of transmission and access to receivers. Study materials have to be effectively designed for "self learning". They must be very clear, interactive, relevant and available media in appropriate ways. They also need to include well designed, unambiguous assessment materials (Carrol, 2004). The material can be entirely print based or use of a variety media, depending on what is available and the effectiveness of different media for learning purposes. They can be created locally or sourced from else where, with or without customisation. It is felt that it is better if the teaching materials be prepared by the team. This however, can be left to the respective department. Preparing of teaching material for one course will be given an average of time load of six month for one instruction.

\section{Efficient logistics}

One deterrent is that distance education normally requires considerable up - front investment to train staff, design curriculum prepare materials and acquire the selected technology. Once this sizeable hurdle is passed, the comparatively modest recurrent costs of the programme can usually covered in large part by student fees. The investment in costly facilities and their maintenance thus enabling more funds to be used in support of teaching inputs and learning activities in crucial to promote education of valour. Logistics covered such things as getting materials to students and ensuring effective communication. In particular students must be able to get their assignments to their tutors and tutors must be able to get the marked assignments back to students.

\section{Students' support services}

In distance education student support is universally understand as the most critical factor influencing student success (Keast, 1997). Timely feed back to students on their performance, on -site tutoring and access to library and laboratory materials are essential for student achievement in tertiary distance education programmes. Without it, student drop-out rates will rise and eliminate any advantages of cost-effectiveness for distance learning. 
Rena, Ravinder (2007) "Challenges In Introducing Distance Education Programme In Eritrea - Some Observations and Implications" Turkey: Turkish Online Journal of Distance Education-TOJDE (ISSN 1302- 6488), (January), Vol.8. No.1. Article 15. pp. 191-205. tojde.anadolu.edu.tr/tojde25/pdf/article_15.pdf

\section{MPLI CATI ONS FOR DEVELOPMENT}

All teachers in Eritrea should receive moral and economic support which is compatible with their level so that they will protect the value of their profession; since teaching and learning is an endless process, teachers should also be given adequate on-the-job training parallel with the technological advancement of the world.

Therefore, the quality of education in Eritrea should go parallel with the development of teachers. Hence, it is to be suggested that the teachers should upgrade their skills through the distance education. The drafted strategies, which are accepted by curriculum designers and makers, to be deployed in open/distance learning institutions, need careful, follow up. The learning strategy that blends several, options where necessary, include upgrading teachers, professionalism and capital building at zoba (province) and local office levels. The open/distance learning institutions established are centres to support Eritrea's open/ distance learning activities, how ever, the materials were created and whichever institutions performed the accreditation functions. Hence, it is suggested that

\section{Material Support}

1) A standard curriculum must be made in the country and books for the distance learning must contain a set of learning outcomes that enable all contact learners what to know understand and do in the on-going courses they will undertake to achieve a certificate, diploma, degree.

2) The study manuals, readers, and study guides must be prepared to the existing Eritrean, external and newly created resources to guide the tutors have the same line in teaching and learning processes and to help the learning to pursue their success studies accordingly.

3) Adequate teaching aid materials like audio, video cassettes, printed material must be prepared to enhance and promote learning in wherever the students are.

4) The MOE or the University of Asmara must posses a printing press. It is unthinkable to start the distance education program in the assumption that teaching materials could be produced by outside printing press.

5) The modules written should reflect Eritrean education system, must be written with their challenges, and the proposed solutions to satisfy many groups of learners.

6) The accusation of a DE expertise in one of the prerequisite for preparation of teaching materials, training and assisting on the total operation of the program helping the academic staff in writing courses is crucial.

7) DE relies more and more on the availability of the internet and the world wide-web must be practiced.

\section{Students Support}

1) Central, regional and local office should be clearly mandated to perform student support function at all levels. 
Rena, Ravinder (2007) "Challenges In Introducing Distance Education Programme In Eritrea - Some Observations and Implications" Turkey: Turkish Online Journal of Distance Education-TOJDE (ISSN 1302- 6488), (January), Vol.8. No.1. Article 15. pp. 191-205. tojde.anadolu.edu.tr/tojde25/pdf/article_15.pdf

2) The offices must inform the tutors to include face-to-face individual support system both personal and academic to encourage learners. And the offices must employ tutors who are committed and dedicated to help learners to overcome their study difficulties.

3) Tutors must become more professional, more interested in pedagogical aspects of higher education and more motivated to integrate their research and teaching interest in a holistic way. This will lead to greater job satisfaction, better academic programs, improvement of student leaning and practitioners' insights and contributions to the advancement and knowledge in higher educations.

4) Tutors should understand more about how learners learn and respect the learners own existing knowledge of structure.

5) Tutors or facilitators must converse with learners and help them understand what they are having difficulty or to challenge and extend an early provisional grasp of course materials.

6) Tutors should encourage support at every possible point in learners' life and tutors should also choose assessment methods to encourage learning involvement.

7) Tutors should be available to assist groups who request help to be able to sort out problems in a constructive way and make simple tutoring while modeling group work.

8) Tutors must encourage where learners meet other learners to set up peer learning group. Besides, tutors engaged in learners support must be provocative in demonstrating the crucial contribution of learners support to prove the success of DE and educational knowledge.

9) Tutors must enable students develop skills of problem solving inquiry, information gathering, analysis, interpretation, communication, and other essential process skills while exercising a learner- cantered approach.

10) Tutors have to be committed to improve their tutorial in order to better assist their learners and have strong interest in strengthening the tutorial system as a whole. Tutors have also to face tremendous challenges like: dedication, creativity and flexibility and be a sensitive to a number of complex issues and have to build leaner centeredness and quality assurance of all levels.

\section{Logistic Support}

1) Central, regional, and local offices should be used to proved good logistic. Things to be accomplished once, tasks that concerns students, groups and tutors should be done locally.

2) The institution which is investing a considerable amount of money in recurrent costs of tutorials and learning centres must surely and extremely interested in promoting action research while serving its tutors and learners.

3) The administration, tutors and the facilitators and the employees must be rewarded, trained, and paid sufficiently. 
4) The central, regional and local office, should be given full responsibilities to perform logistical function to ensure the smooth running of DE institutions.

5) Quality materials must be bought to motivate the learner while pursing their overall studies.

6) The concerned offices should allocate a good budget to buy modern devices like enet; computers based learning programs, CD-ROMs, print media, Audio/ video cassettes, video conferencing and the web.

7) Central, regional and local offices must strive to build institutions well equipped with quality material, libraries, and laboratories.

Institution/ Centre Selection

In order to select appropriate site for opening DE centres in different regions of Eritrea, it is advisable to take the following points into account.

1) The availability of organized post office telephone services and the availability of secondary school.

2) Easily accessible to students in the area and reasonable number of student recommended is not to be lees than 60 students.

3) Institution must surely and extremely try to resolve problems that could arise in the courses of time.

4) Institution must encourage its departments and staff to undertake evaluation of different kinds. It must be committed to quality assurance and continually involving staff in assessment and self-evaluation.

5) Institution must make space available and study group use at times suitable and convenient for learners (i.e. study centres).

6) Institutions must employ the tutors who are committed and dedicated to help learners to overcome study difficulties.

7) Institution must include face-to-face individual support system both academic and personal that encourages learners' centeredness. Institution must contain quite a number of role players: a course coordinator, the regional or local tutors, administrative staff and the tutors.

8) Institution should embrace learners concerning activities based on the expressed needs of learners with their specific circumstances.

\section{CONCLUSION}

It is challenging to study critically about any given model of distance education at the starting in the country. However, an attempt is made to study carefully all the distance education programmes ever tried by the government. The distance education is changing with an alarming speed, particularly as educational processes become increasingly globalize in terms of physical reach and scope of courses and programmes 
Rena, Ravinder (2007) "Challenges In Introducing Distance Education Programme In Eritrea - Some Observations and Implications" Turkey: Turkish Online Journal of Distance Education-TOJDE (ISSN 1302- 6488), (January), Vol.8. No.1. Article 15. pp. 191-205. tojde.anadolu.edu.tr/tojde25/pdf/article_15.pdf

of study offered. Eritrea has launched distance education programmes but hampered due to various factors. In distance learning students and teachers $w$ ill find themselves playing different roles than is the norm in traditional education. More than any other teaching method distance learning which exercises new mode of delivery, requires a collaborative effort between student and teacher unbounded by traditional limits of time, space and single instructor effort. Distance education as a provision will undoubtedly help the learners to enhance the acquisition of new knowledge and skills to lead a better life. Hence, joint work of the government and private sectors is needed to lay a firm ground to the implementation of the correct programmes. Since Eritrea is a young nation with 15 years of age needs to establish the strategy for the development of its education through the distance education and thus achieve selfsufficiency in this sector.

Notes:

${ }^{1}$ Provisional Government of Eritrea (1991) Department of Education, Policy of Education, (October 2).

${ }^{2}$ Most of the students or the youngsters are working under national service just for the payment of Nacfa 145 (less than $\$ 7$ dollars) per month. It is obvious that the amount is not sufficient to meet the common expenses like taking tea and snacks; hence they have to work in many places in order to win the bread and survive in the society.

\section{BI ODATA and ADDRESSES of AUTHOR}

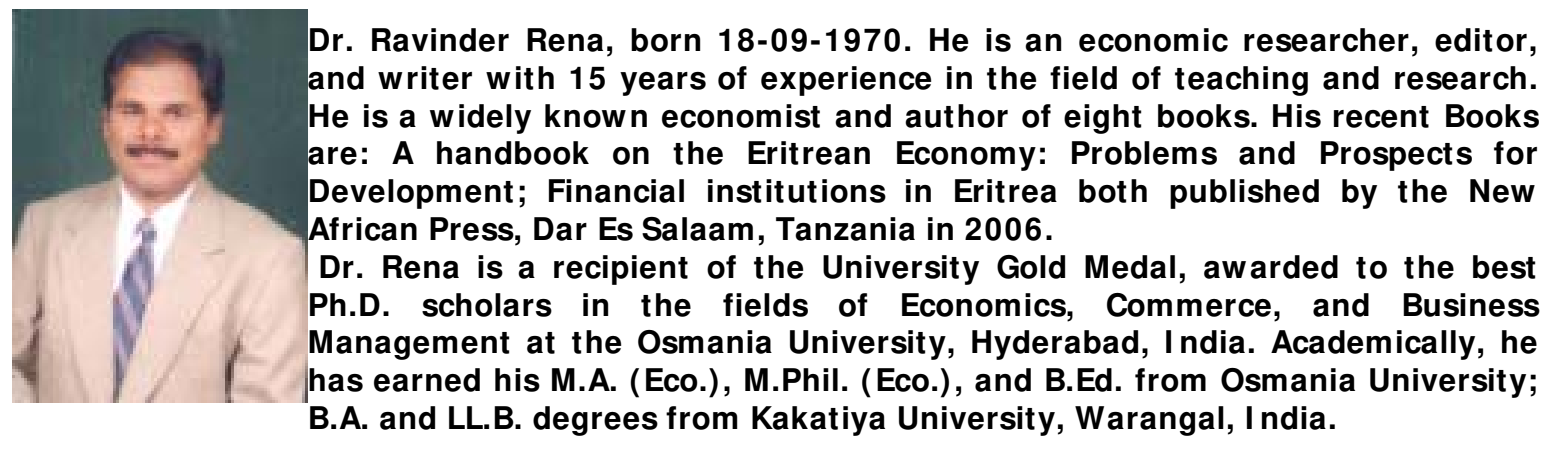

He has been working in Eritrea for the last one decade, currently working at Eritrea Institute of Technology - Mai Nefhi (under the Ministry of Education) in the State of Eritrea since 2004. He has also served as a Senior Lecturer and Head of the Dept. of Economics, Banking and Finance at Asmara Commercial College (under the Ministry of Education) in the State of Eritrea during the period 1997-2004. Prior to this he worked as a Lecturer in India. His areas of specialization in teaching are: business and managerial economics, banking and finance, development economics, research methods, the Eritrean economy, and economics of education and agricultural economics, in research.

He is been based in Eritrea for a decade, and has written more than 100 articles (mostly on Eritrea and Africa) in peer reviewed international and national journals, magazines, and newspapers such as: Finance India, Eritrean Studies Review, Global Child Journal, African Development Review, Eastern Africa Journal of Humanities and Sciences (EAJHS), The African Symposium, Africa Quarterly, Manpower Journal, Osmania Journal of Social Sciences, Indian Journal of Millennium Development Studies, and Journal of African and Asian Studies, Eritrea Profile, kalingga among others. Further, he is an editorial board member, Global Child Journal (U.S.); editor, Science Vision (Eritrea); on the board of directors of the WOMEN (Women Organization Micro Finance Education Network), an international NGO based in U.S.; and advisor to the board of the To Love Children International NGO, based in U.S. Dr. Rena also serves as a reviewer for the International Journal of Educational Development using ICT, The African Symposium, and African Studies Review. 
Rena, Ravinder (2007) "Challenges In Introducing Distance Education Programme In Eritrea - Some Observations and Implications" Turkey: Turkish Online Journal of Distance Education-TOJDE (ISSN 1302- 6488), (January), Vol.8. No.1. Article 15. pp. 191-205. tojde.anadolu.edu.tr/tojde25/pdf/article_15.pdf

Dr. Ravinder Rena

M.A., B.Ed., LL.B., M.Phil., Ph.D.

Assistant Professor of Economics

Dept. of Business and Economics

Post Box No: 7956

Eritrea Institute of Technology- Mai Nefhi

(Under the Ministry of Education)

Asmara, Eritrea.

Email: ravinder rena@vahoo.com, ravinder rena@rediffmail.com

\section{REFERENCES}

Araya, B. (May, 1998). Project Evaluation: DEPETE Phase-I, University of Asmara, Eritrea.

Carrol, D. ( February, 2004). Pedagogy and Assessment in the new curriculum. Ministry of Education, Asmara, Eritrea.

Daniel, J.S. Mega, (1996). Universities and Knowledge Media, Technology Strategies for Higher Education. London, Kogan Page Ltd.

Harry, K. (1992). Distance Education today and tomorrow. A personal Perspective. Educational Media International, 29(3), 189-192.

Keast, D.A. (1997). Towards an Effective Model for I mplementing Distance Education Programs. American Journal of Distance Education, 11(2), 39-55.

Keegan, D. (1996). The Foundation of Distance Education. London: Croom Helm.

Keegan, D. and Rumble, G. (1982).Distance teaching at University level. In Rumble, G. and Harry, K (ed) Distance teaching Universities. New York: St. Martins press, p.15.

Keegan, D. (1983). On Defining Distance Education. In Stewart, D. Keegan, D. and Hoeberg, B.(Eds.) Distance Education. New York: St. Martins press, p.27.

Khan, J. (1993). Human Resource Development in the public sector; A Developing Country experience, International Journal of Public Sector Management 61(1), 48-58.

Killion, T. (1998).Historical Dictionary of Eritrea. Lamhom: Scarecrow Press.

Marrs, L. (1995). An Analysis of Distance Education and Educational Technology. Offices of continuing Education and Information and Telecommunication Services. Bellingham, Washington: Western Washington University.

Ministry of Education, UNESCO and the Government of Italy (1996). Guidelines for Policy Framework on Open and Distance Education. Asmara: Eritrea. (January 23).

Ministry of Education (June 1999). Our People are our future: A frame work for the development of human resources in the education sector. Asmara: Ministry of Education.

Ministry of Education (2003). Eritrea: Basic Education Statistics 2002-2003. Eritrea. Asmara, Ministry of Education.

Ministry of Education (2006).Tertiary Education in Eritrea: I ssues, Policies, and Challenges. 13 (56 and 57) (Part- I and II on 20 and 23 September). Eritrea Profile p.2-3. 
Rena, Ravinder (2007) "Challenges In Introducing Distance Education Programme In Eritrea - Some Observations and Implications" Turkey: Turkish Online Journal of Distance Education-TOJDE (ISSN 1302- 6488), (January), Vol.8. No.1. Article 15. pp. 191-205. tojde.anadolu.edu.tr/tojde25/pdf/article_15.pdf

Ministry of Education Brief Description of DEPETE: Tasks and Achievements, Department of National Pedagogy, Ministry of Education, Asmara, Eritrea.

Moore, M.G. (1990). Recent Contribution to the Theory of Distance Education. Open Learning, 5 (3), 10-13.

Moore, M. G. (1994). Is the cultural problem in International Distance Education? In Melody M. Thompson(Ed) Internaitonalism in Distance Education: A vision of Higher Education.

Moore, M. G. and Kearsley, G. (1996). Distance Education: A System View. Belmont: California: Wadsworth Publishing.

Rena, R. $\left(2005^{\mathrm{a}}\right)$. Gender Disparity in Education-An Eritrean Perspective, USA: Global Child Journal_2(1),43-49.

Rena, R. $\left(2005^{\mathrm{b}}\right)$. Eritrean Education - Retrospect and Prospect, Nairobi (Kenya): Eastern Africa Journal of Humanities and Sciences, 5(2).1-12.

Rena, R. $\left(2005^{c}\right)$. Financing of Education in Eritrea-A Case Study on Zoba Maakel, Albany (USA): The African Symposium, 5(3) 113-128.

Rena, R. (2006). Education and Human Resource Development in Post-independent Eritrea-An Analysis, Barbados (West Indies) I International Journal of Education and Development using Information and Communication Technology (IJEDICT), 2006, Vol. 2, I ssue 4.

Rumble, Grevile and Joao Oliveria (1999). Vocational Education at a Distance. International Perspectives. London: Kogan Page.

Saint, W. (1999). Tertiary Distance Education and Technology in Sub Saharan Africa. Washington, D.C.: The World Bank, ADEA working group on higher education.

Sweet, R. (1986). Student Drop Out in Distance Education the Foundations of effective Practice. San Francisco, Calilfornia: Jossey - Bass Publishers.

Taye, A. (1992). A Historical Survey of state of Education in Eritrea. Asmara: Educational Materials Production and Distribution Agency (EMPDA).

Terry, E. \& Philip J. (1991). Research in Distance Education, London: Macmillan 1991:1. Wills, B. (1998). Effective distance education planning: lessons learned. Educational Technology, 38 (1), 57-59.

Wood, H. (1996) Designing Study Materials for Distance Students, New York: Dryden Press.

$$
* * * * *
$$

